\title{
Implementation of Computer Graphics on 3D Animation "Good Manners of Ghatotkacha"
}

\author{
Wahyu Pujiyono $^{1}$, Yana Hendriana ${ }^{2}$, Ade Nuru Trisnawan ${ }^{3}$ \\ ${ }^{1,2,3}$ Informatics Department, Faculty of Industrial Technology, Universitas Ahmad Dahlan, Indonesia
}

\begin{abstract}
In the Modern Age, the children are less familiar with puppets. Lack of children in recognizing the puppet is due in the beginning, the puppet was created for adults. Foreign cultural influences cause children to prefer entertainment from the outside, like a cartoon of the familiar puppets. As a result, the Indonesian people increasingly forget traditional culture to culture because it does not stand alone, one only is the art of puppetry. The proof, the art that is "valuable" is less familiar to children as a potential replacement for generations to come. Based on the above, further research will be done to create 3-dimensional animated puppet movie Ghatotkacha. The film was made with the Indonesian leather puppet culture-based computer graphics.

The methodology used to obtain specifications animated film Ghatotkacha Exemplary Good is interview, observation, and literature. Animated film done by the method of 3dimensional animation production pipeline: pre-production, production and post-production. Ghatotkacha animated film tested by the method alpha test and the black box test.

From the making of the film, the final result Ghatotkacha animated film A Good Example. The animated film introduces the puppet culture to children. Ghatotkacha animated film was also made to appreciate the culture of Indonesian puppet. Alpha testing and black box test test carried out on the animated film Ghatotkacha. The test results showed that Ghatotkacha animated film is an animation with puppets culture of Indonesia. Ghatotkacha animated film is a cultural appreciation for the puppet to convey positive values for children aged 6 to 12 years.
\end{abstract}

Keywords - $3 D$ animation, cultural, children's film, Ghatotkacha, puppets.

\section{INTRODUCTION}

Puppet is a work of art that has a great culture noble values, which deserves to be taught to children as heir to the nation. In modern times, as now, the children are less familiar with puppets. Lack of children in recognizing the puppet is due in the beginning, the puppet was created for adults. Puppet show has been recognized by UNESCO on November 7, 2003. Considering the culture (traditional) forms part of the national culture, it is necessary to preserve the culture of the area as a puppet so that from an early age children are aware of the culture of the area [1].

Along with advances in technology, the development of today's entertainment has been so rapid. Children easily get modern entertainment, ranging from video games, animated films, and other entertainment. Figures of foreign films are already familiar with the children. Developments in the entertainment realm, finally bringing negative impact on the culture among children, with increasingly forgotten figures of folklore (traditional stories). For example characters in puppet.

Developments in the animated film cannot be separated from the development of computer graphics. Graphic can consist of 2D or 3D image can be completely artificial or can be produced by manipulating the image [2]. Manipulation used in the figure on the animated film is the translation, rotation, scaling [3]. Developments in the field of multimedia software, especially for animated films also is rapidly increasing along with the times. One of the popular 3D animation software today is Autodesk Maya. In the making of the $3 \mathrm{D}$ animated film, especially in the manufacture of a character or other model-based 3D in Autodesk Maya, can use the Polygon Primitives to develop its 3D models. Based on the background of the above problems, it is done research to create 3dimensional animated film with Indonesian culture.

\section{LITERATURE REVIEW}

The first study refers to previous research conducted by Puji Handayani. The study, entitled "Method Animation implementation Frame By Frame And Tween In Cartoon Film Making" hare Got The rock "in 2012. His research makes film 2D animation to convey the story of the deer hit the stone taken from folklore. Types of films are made, can be watched at any time. Tell the deer that likes to steal cucumber farmer pack, then framed by a pack of deer farmer so that he gets as a result of his actions [4].

A second study refers to previous research conducted by Chabib Syafrudin. Research thesis entitled "Making Animated Short Film" Fierce Alms "Multimedia-Based Techniques Using 2D Hybrid Graphic Animation With Utilization" in 2012. In research, conveying religious values to the audience of charity that his deeds obtained from the state of daily life -day in the animated film "Fierce Alms" [5].

The development of information technology, especially the gaming industry which is one of the growing gaming industry is important for brain development, to improve concentration and train properly and solve problems quickly because in the game there are various conflicts which requires us to solve it quickly and precisely [6].

Early Childhood Education (ECE) is very important to do well in a home environment as well as in the educational environment of pre-school. Education preschool children at age 2 to 3 years is the formation of character, where education is stressed here in the picture, sound and movement combined with an attractive shape and color. At this age children begin 
to recognize the objects around it. The introduction of culture is also one of the curriculum in pre-school education [7].

The main objectives for developing the website are to educate the community on the benefits of performing the working memory test of the activity of the brain and improvements in social skills and improving poor academic and professional performance, especially in maths and reading comprehension [8]. A large number of literatures have been dedicated to the development of goal modeling, result modeling, ratings and rankings for games prediction [9].

The learning effectiveness and motivational appeal of a computer game for learning computer memory concepts, which was designed according to the curricular objectives and the subject matter of the Greek high school Computer Science (CS) curriculum, as compared to a similar application, encompassing identical learning objectives and content but lacking the gaming aspect [10].

The flow theory is used as a framework to facilitate positive user experience in order to maximize the impact of educational games. Especially, the factors that contribute to flow experience are discussed. The experiential gaming model can be used to design and analyse educational computer games. However, the model works only as a link between educational theory and game design and does not provide the means to a whole game design project [11].

The use of educational games in learning environments is an increasingly relevant trend. The motivational and immersive traits of game-based learning have been deeply studied in the literature, but the systematic design and implementation of educational games remain an elusive topic [12].

\section{A. Computer Graphic Systems}

Computer graphics system is a computer system, therefore, should have all the components of a general-purpose computer system. Display high-level graphics system is shown in Fig.1. Computer graphics system is a computer system, therefore, should have all the components of a general-purpose computer system. Display high-level graphics system is shown in Fig. 1 [3].

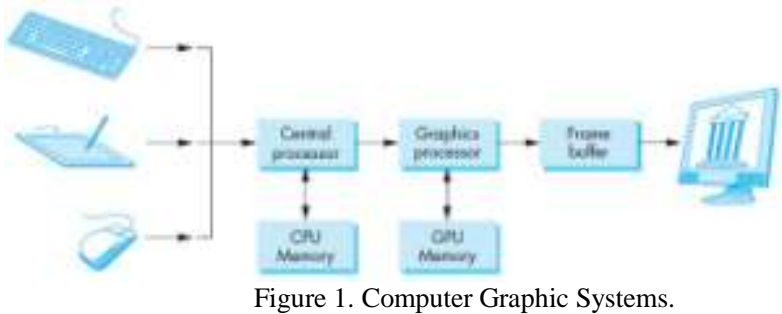

There are six main elements in the system:

(1) Input devices

(2) Central processing unit
(3) Graphics processing unit

(4) Memory

(5) Frame buffer

(6) Output devices.

This model is quite general includes workstations and personal computers, interactive gaming systems, cell phones, GPS systems, and sophisticated image generation system. Although most of the components in the computer are standard, it is a special element for computer graphics that characterize as a portrait graphics system.

\section{B. Coordinate System}

EBasis vectors v1, v2, and v3 defines the coordinate system. Three vectors form a coordinate system as in fig. 2. With three vectors that can be used as a basis appear to represent any vector in three dimensions. In the 3-dimensional space, the vector has a direction and magnitude [3].

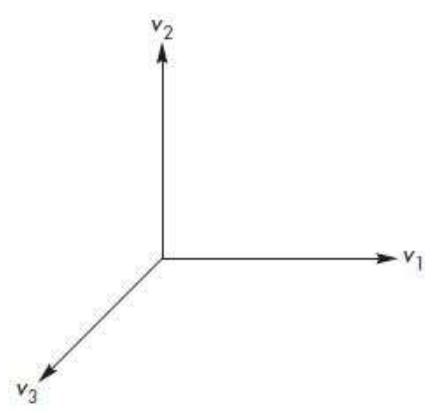

Figure 2. Vector

\section{Primitives and Attribute}

Primitives are orthogonal, each providing the capabilities of the system. A minimum of primitives typically support lines, polygons, and some text formof (sequence of characters), all of which can be produced efficiently in hardware. On the other is a system that can support a variety of primitives, such as circles, curves, and surfaces. The argument here is that the user must be a primitive to build sophisticated applications with ease [3].

\section{Colors}

Colors can be seen as a point in a solid color. The distance along the coordinate axes represent the number of corresponding primary in color. Each color produces primary set as a point in the unit cube. Cube vertices correspond to black (not primary), red, green, and blue (as the primary set), cyan (green and blue), magenta (red and blue), yellow (red and green), and white. Solid color shown in Fig. 3. [3]. 


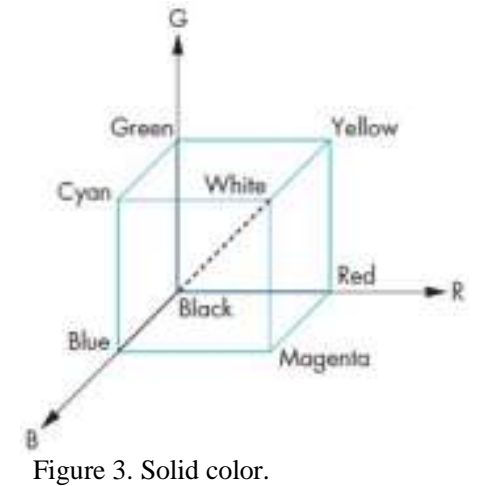

In applications where it will assign colors to each point, can put color RGB (red, green, and blue) into a separate data structure, as in OpenGL:

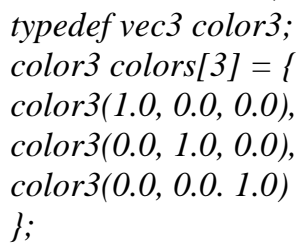

\section{E. Light Sources}

Usually light sources (light sources) are objects that emit light only through an internal energy source. A light source such as a light bulb may reflect more than one light [3].

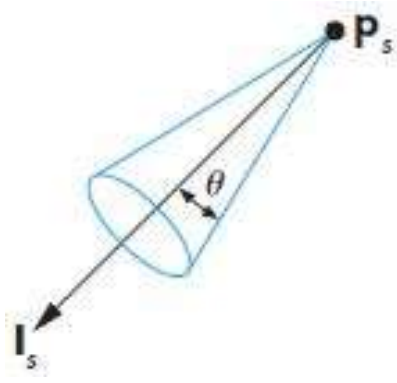

Figure 2.4. Spotlight.

Fig. 4. shown example of a spotlight. Spotlight (spotlight) has the characteristics of a narrow range of angles in which light is emitted. Spotlight can simply be dibut of point light sources by limiting the angle where the light from the source can be seen. Cones can be used as a peak (PS) which is heading in the direction (LS), and its width is determined by $\Theta$ angle, as shown in the picture. If $\Theta=180$, spotlight a point source of light.

\section{F. Transformation}

Transformation is a function that takes a point and map to another point. There are three parts transformation, ie translation, rotation, and scaling [3].

Translation (translation) is an operation that changed the point by a fixed distance in a given direction, as shown in Figure 2.5. To determine the translation, need to determine the displacement vector $\mathrm{d}$, because of the change point is given by:

$$
\mathbf{P}^{\prime}=\mathbf{P}+\mathbf{d}
$$

for every point $\mathrm{P}$ on the object.

Description :

$\mathrm{P}^{\prime}$ : position of the object after translation

P: initial position of the object

$\mathrm{d}$ : the value of the object translation

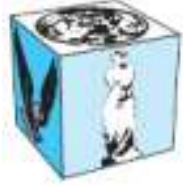

(a)

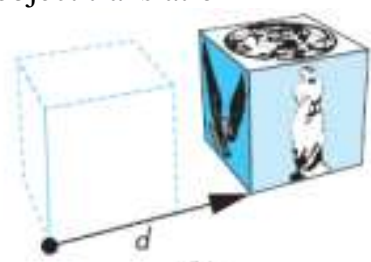

(b)
Figure 5. (a) Object to the original position. (b) The object is done translation.

Rotation (rotation) a little more difficult in the determination of the translation. Changes in the degree of rotation lies in the amount committed. A simple example of the rotation point on a two-dimensional plane, as shown in Fig. 6.

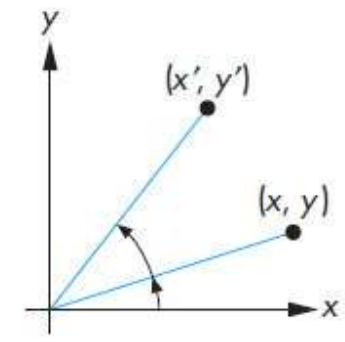

Figure 6. Two-dimensional rotation.

Scaling (scale) affine transformations that can make the object larger or smaller. Fig. 7 illustrates the scale. Cube object can be transformed into smaller or larger.

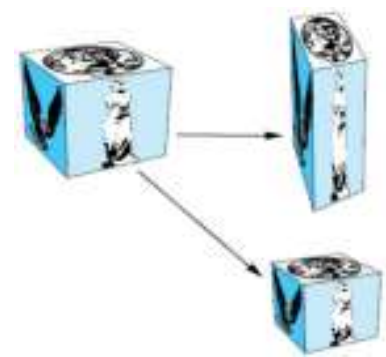

Figure 7. Illustration scaling.

\section{G. Pipe Production}

A pipe production for most of the projects can be broken down into three stages: pre-production, production and post-production. The stage of making the animation and then distributed among several departments, depending on the type of project and what shipping way eventually. Fig. 8 is a stage in making a 3D animation [13]. 


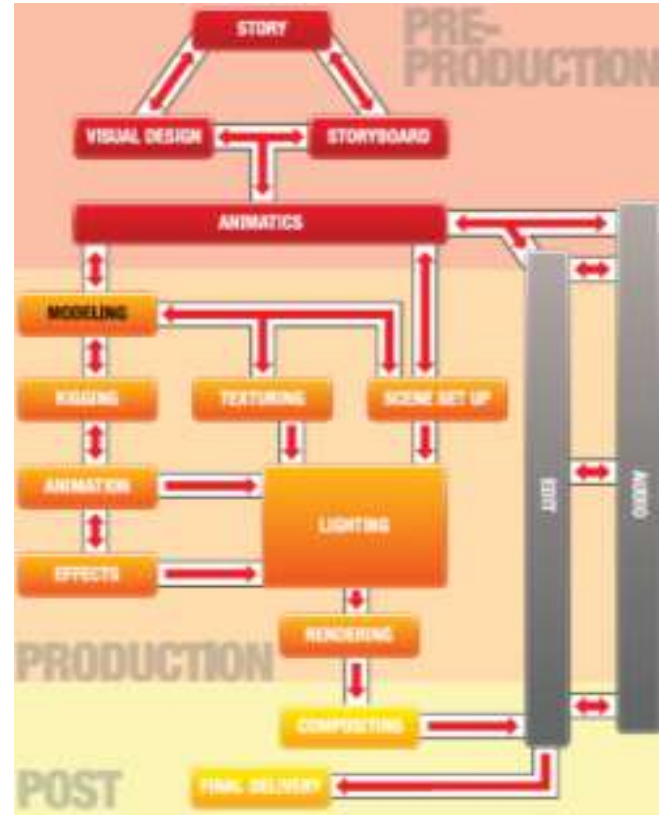

Figure 8. Stages of making animation [13]

\section{III.RESEARCH METHODS}

\section{A. Method of collecting data}

1. Interview

The first interview is done to the puppeteers, namely Dr. Junaidi, S.Kar., Hum. The interview is intended to determine the leather puppet stories suitable for the manufacture of animated films.

The second interview to the storyteller children, namely Muhammad Puji Kurniawan, S.sos.I. This interview was conducted to determine the appropriate storytelling to children.

The third interview to psychologists, Drs. Hadjam Murusdi, M.U. Interviews were conducted to determine the age range of the child and exciting way to make animated films for children.

\section{Observation}

Observations carried out by directly observing the children's animated films and understand the story line and the things that make interesting animated film watchable. Animated film is observed Tom and Jerry with the title of the film "Tomcat Jetpack" and "Fire Breathing tom cat" and Upin Ipin titled "Fly high (Courant 1)" and "Fly high (Courant 2)".

3. Literature

The collection of data with the source books about making animation. This objective is to determine the steps to create 3D animated film is good. The books include: "Designing a Movie Cartoon World Class" [14], "3D Animation Movie using 3DStudioMax" work [15], "Digital Modeling" by [13], and "Interactive Computer Graphics: A top-down approach with shader-based OpenGL "by [3].

\section{B. Analysis}

Analysis to create a movie specifications. Based on data collected from various sources, the data is further analyzed to serve as specifications animation filmmaking. Specifications animated films are: (1) The animated film intended children aged 6 to 12 years. (2) The story of animated films made of the story the main character puppet with Ghatotkacha by displaying good values from these figures. The values that will be delivered is Ghatotkacha a studious, spirited leader, and smiling. (3) Submission of the story do not use offensive language, the plot should be clear. (4) Animation made as attractive as possible so that children do not feel bored, creating a situation itecmen and couping focus concept that children idolize and make himself seems to be his idol in the animated film. In addition, the main character must always be made great. (5) Duration is used in the animated film that is 3 minutes.

\section{System Design}

Creating an animated film is necessary to design the system. Pre-production, which is done to develop the phase of each asset animated film is: Story, Visual Design, Storyboard, Audio: Scratch Voice Recording, Animations, and Audio: Voice Recording.

\section{Implementation}

Implementation is the process of execution of the asset is developed at the design stage of the system. Stages in implementation are:

1. Production

Production stage include:

Modeling, Texturing, Rigging, Scene setup, Animation, Lighting, and Rendering.

2. Post Production

Post-production stage include: Compositing and Final editing and delivery.

\section{IV.RESULTS AND DISCUSSION}

\section{A. Results and Implementation}

1. Pre-Production

a. Story

A primary school age children will introduce himself, he named Ghatotkacha. Ghatotkacha has a duty (PR) to be resolved. Ghatotkacha learn happily, he studied with prayer begins, do not give up, and try to understand the material textbooks. After reading the textbook, he was immediately his homework it. Ghatotkacha could answer all his homework properly.

\section{b. Visual Design}

Making the visual design Ghatotkacha character made like primary school children by the age of 10 years. Visual design Ghatotkacha character shown in Fig. 9. Visual design created with character front and side. 


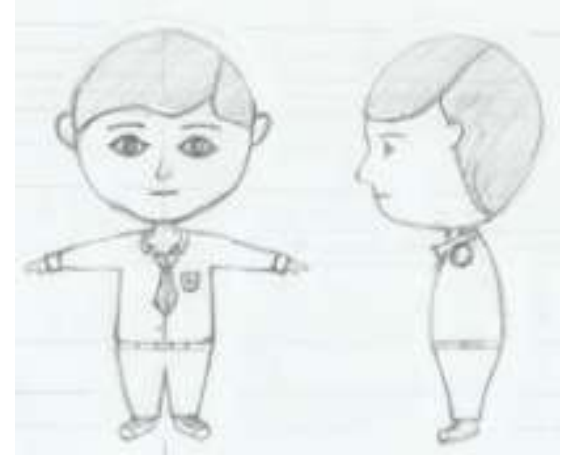

Figure 9. Ghatotkacha design.

c. Storyboard

Making the action of running the existing visual on Ghatotkacha animated film. Fig. 10 shows character action Ghatotkacha running. Figure 10 (a) is a character in the rear position. Figure 10 (b) is the position of the characters move toward the front.

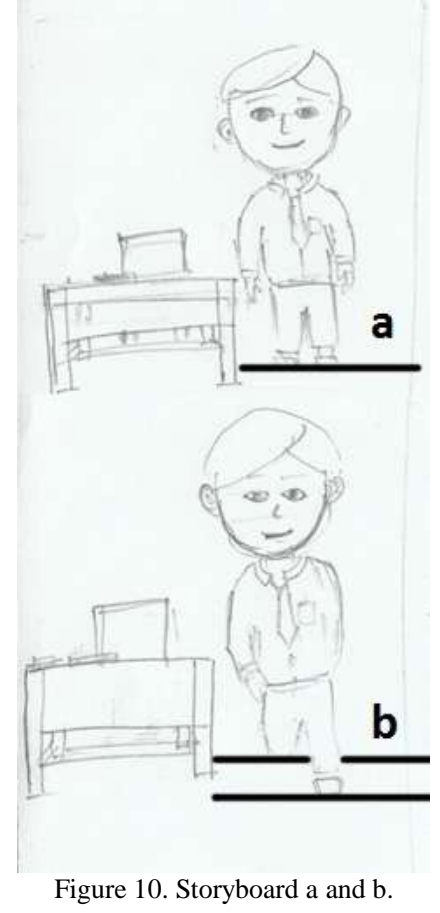

d. Audio: Scratch Voice Recording

Voiced Ghatotkacha character is Chairil Tale (age 19 years).

\section{e. Animatics}

Animatics animated film Ghatotkacha equipped with an image scene, duration, camera, location, and musical illustration.

f. Audio: Voice Recording

Sound recording performed by the dubber Chairil Ghatotkacha character saga.

\section{Production}

a. Modeling

The process of making 3D models for animation films Ghatotkacha. Modeling starts with writing the script Maya Embedded Language.
Table 1. Code primitive objects tube.

\begin{tabular}{|l|c|}
\hline No. & Script \\
\hline 1. & \multicolumn{2}{|c|}{ polyCylinder -r 1 -h 3 - } \\
sx 20 -sy 1 -sz 1; \\
\hline 2. & // membuat objek \\
& primitif tabung // \\
\hline
\end{tabular}

Primitive objects tubes developed to create 3D models of characters Ghatotkacha. Fig. 11 is the character models Ghatotkacha.

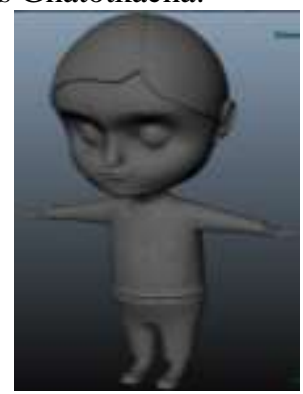

Figure 11. Ghatotkacha character models.

In the modeling stage, also made a model of facial blend shape. It is for the expression of the character's face Ghatotkacha. Ghatotkacha blend facial shape can be seen in fig. 12 .

b. Texturing

Texturing character is done with the addition of color and texture. Texturing done by adding color to an object with such a uniform primary school children. Color clothes elementary school in Indonesia is white and red. White color for the shirt and the red color for pants and ties. Texturing results can be seen in fig. 12 .

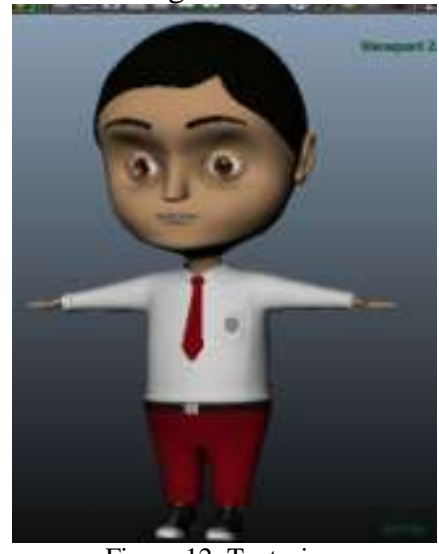

Figure 12. Texturing.

\section{c. Rigging}

Reinforcement done with bone preparation mimics the framework of the human body. Reinforcement works to the motion system Ghatotkacha character. The composition of reinforcement character look green. Reinforcement results can be seen in Fig. 13. 


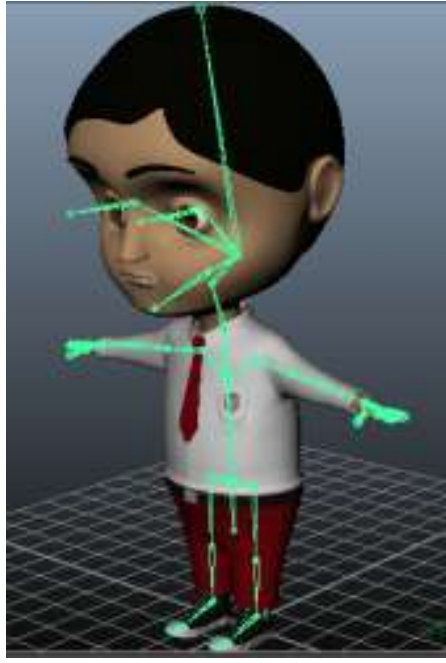

Figure 13. Rigging.

The controller plays an important role in the process to turn the character animation. The composition of the controllers on the character Ghatotkacha look green around the body. Controller Ghatotkacha character can be seen in fig. 14 .

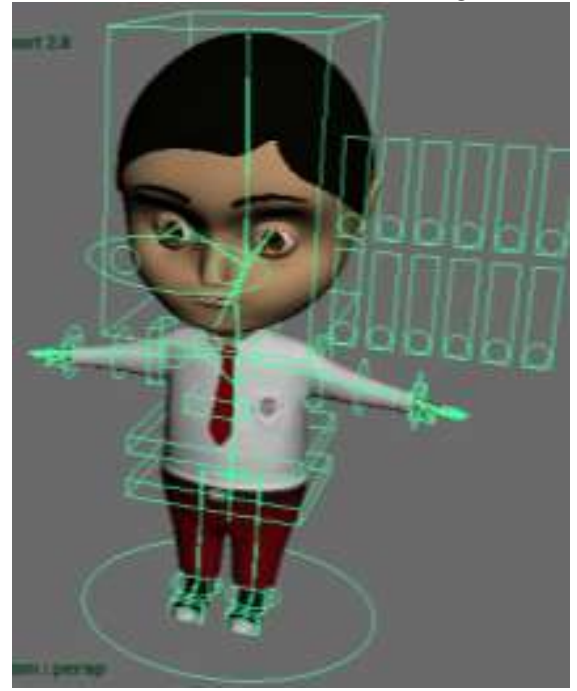

Figure 14. Ghatotkacha character controller.

Each controller must be proper preparation of the hierarchy. The controller on the character Ghatotkacha prepared by placing the appropriate hierarchy. Controller will make it easier for animators to do animating.

d. Scene setup

Adjust the layout of objects in 3-dimensional space. Objects are arranged layout of tables, chairs, Indonesia map, photograph, and character in the classroom. The setting serves to turn the animated environment. Results arrangement of objects in 3D space can be seen in Fig. 15.

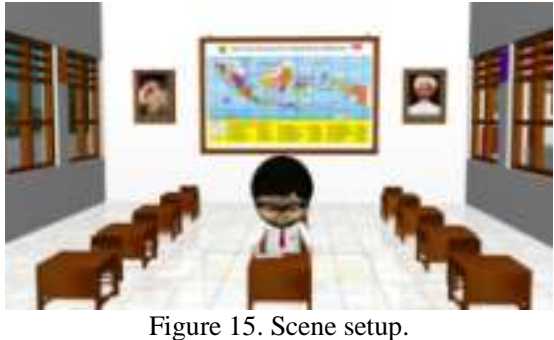

e. Animation

Animators animate a character with a wide range of motion. Animators animate characters with expression. Sketching pose a very important key to the process animation.

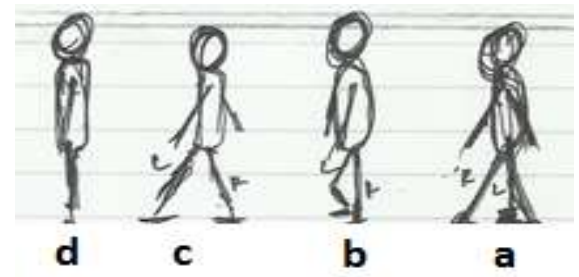

Figure 16. Sketch key poses.

Fig. 16 is a key poses. Figure 16 (a) a first key characters pose for a walk. The show poses pose right leg to the front, left foot back, left arm forward and right arm backward. Height at this position is low because it opens the legs to the front and rear. Figure 16 (b) a second key characters pose for a walk. Pose the right foot upright, left leg bent backward and lifted from the surface of the foothold, the position of both hands beside the body. Height in this pose is the maximum height because one leg is perpendicular. Figure 16 (c) form third key poses. This poses sam the first pose. The position of the right leg is behind, the position of the left leg is in front, next to the left hand and right hand to the back. Height at this position is low because it opens the legs to the front and rear. Figure 16 (d) a fourth key poses. The pose suggests the end of a running pose. This poses both feet on the perpendicular. Both hands are next to the body, perpendicular. Height in this pose is the maximum height because one leg is perpendicular.

Animators began to animate characters by reference storyboard and animatics. Animation Ghatotkacha character can be seen in Fig. 17.

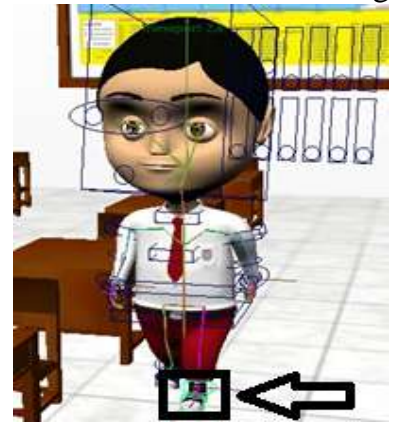

Figure 17. Animation Ghatotkacha. 
Fig. 17 shown the picture there is a black box that is shown by the arrows. Animation initial placement is in the frame 1 . The initial placement of the frame shown in 4.2 no script. 1 . The controller is green in the black box shows the selection left foot controller, like the script 4.2 no. 2 . The controller translates to a value of 0 on the $\mathrm{X}$ axis, 0.055 on the $\mathrm{Y}$ axis, and 0212 in the Z-axis as the script 4.2 no. 3. The translation produces a left-footed forward direction to the process of shooting went. Translational left foot controller is locked with the function of the script setKeyframe 4.3 No. 4.

\begin{tabular}{|l|l|}
\multicolumn{1}{|c|}{ Table 2. Ghatotkacha character code translation feet. } \\
\hline No. & Script \\
\hline 1. & currentTime 1; \\
\hline 2. & select -r kontroler_kiri_kaki_engkel1; \\
\hline 3. & move -r 0 0.055 0.212; \\
\hline 4. & $\begin{array}{c}\text { setKeyframe } \\
\text { \{"kontroler_kiri_kaki_engkel1" \}; }\end{array}$ \\
\hline
\end{tabular}

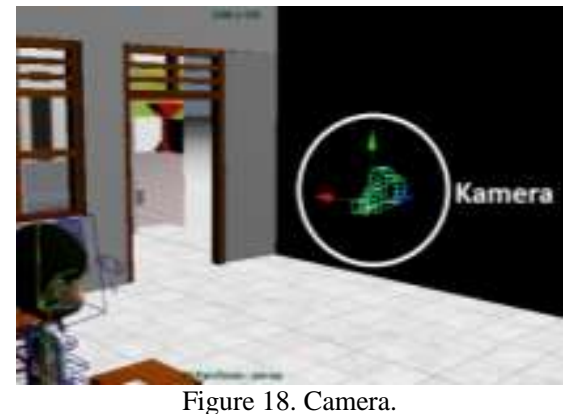

Fig. 18 is the placement of the camera on the animation Ghatotkacha. Animation done not only on the characters. Animation done also on the camera. The camera leads to the movement of characters during animation. Cameras shooting every frame in the animated film Ghatotkacha.

\section{f. Lighting}

Lighting by using a spotlight has beam characteristics such as a flashlight. These characteristics make the lighting focus to the intended direction, namely in the animation space Ghatotkacha.

\begin{tabular}{|l|l|}
\multicolumn{2}{|c|}{ Table 3. Spotlight. } \\
\hline No. & Script \\
\hline 1. & spotLight -coneAngle 179.994; \\
\hline
\end{tabular}

Table 3 is making code spotlight. Spotlight opened with 179 994-degree opening angle. Each spotlight is positioned above the 3-dimensional animation space. This placement aims at directing the light from the top toward the bottom in the $3 \mathrm{D}$ animation space.

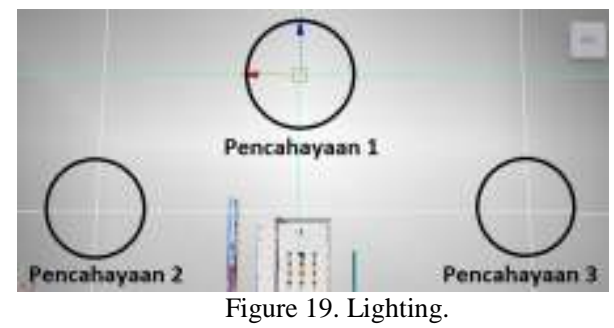

Fig. 19 shown an animated space lighting Ghatotkacha. 3 spotlight lighting use. Spotlight 1 shown in black circles "Lighting 1", spotlight 2 is shown in a black circle "Lighting 2", and the spotlight 3 is shown in a black circle "Lighting 3". Lighting aims to ensure every part of the 3-dimensional animation space to get the appropriate light. With lighting, objects in the animation Ghatotkacha will look.

\section{g. Rendering}

All the elements in 3-dimensional space is done rendering animation. Ghatotkacha frame animation rendering resolution is $1280 \times 720$ pixels. Ghatotkacha character object elements, tables, chairs, and classroom combined into frames. These frames to be processed into an animated movie. To combine all the elements of animation that is used plug-in. Plug-ins render rendering mental ray is used. Plug-in mental ray can be seen in Fig. 20.

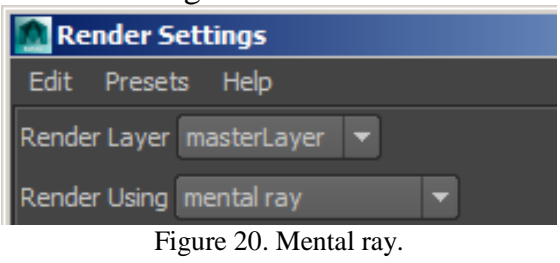

Hardware specifications that are used for rendering are: (1) Processor $3.4 \mathrm{GHz}$ Intel i7 3770, (2) VGA card Nvidia Quadro 2000 1GB, (3) Memory 16GB, and (4) Hard Disk Drive 2TB. The process of rendering the animated film Ghatotkacha spent a total time of 8 hours and 37 minutes. The resulting frame is 2650 with an average of 11,506 seconds for one frame.

\section{Post production}

\section{a. Compositing}

File rendering with mental ray results combined in compositing process. All aspects of animated filmrelated music, sound character, and enhanced video transition at this stage.

\section{b. Final Edit And Delivery}

Ghatotkacha animated film is packaged in a compact disk (CD) to be distributed.

\section{c. Testing}

Testing was conducted using alpha test to students, student, and teacher. Based on testing alpha test, Ghatotkacha 3D animation film is the animated film of Indonesian culture that convey positive values for children aged 6 to 12 years. The first black box testing performed to the $3 \mathrm{D}$ animation expert. The first is based on black box testing, Ghatotkacha animated film made with good planning and produce a film that is able to convey positive values. The second black box testing performed to an expert puppet story. Based testing second black box, Ghatotkacha animated film is an animation with puppets culture that convey positive values and to big apresiation puppet culture in the context of the story regularly. Black box testing the third to the psychologist. Based on the third black box testing, the animated film Ghatotkacha an 
interesting movie to watch with puppets culture. Animation Ghatotkacha have a positive influence in the study with a duration of a movie that is suitable for children aged 6 to 12 years.

\section{CONCLUSION}

Application of computer graphics to produce animated Ghatotkacha animated film with puppets culture of Indonesia. Film animation "Good Manners of Ghatotkacha" made to appreciate the culture of Indonesian puppet. Ghatotkacha animated films convey positive values for children aged 6 to 12 years. Ghatotkacha animated film made with good planning and produce animated films are able to convey positive values. Ghatotkacha animated film is an animation with puppets culture that convey positive values in the context of the story regularly. Animation Ghatotkacha also to appreciate the culture of Indonesian puppets. Ghatotkacha animated film is an interesting movie to watch with puppets culture and have a positive influence in the study with a duration of a movie that is suitable for children aged 6 to 12 years.

\section{REFERENCES}

[1] Junaidi. 2010. Mengenalkan Wayang Kepada Anak: Masa Kecil Pandawa dan Kurawa (Seri 1). Solo: PT Tiga Serangkai Pustaka Mandiri, 2010.

[2] Shirley, Peter. 2009. Fundamentals of Computer Graphics. s.1. : CRC Press, 2009.

[3] Angel, Edward. 2012. Interactive Computer Graphics : a top down approach with shader-based OpenGL. s.l. : Pearson, 2012.

[4] Handayani Putri, Puji. 2012. Implementasi Metode Animasi Frame By Frame Dan Tween Dalam Pembuatan Film Kartun "Kancil Kena Batunya". Skripsi. Yogyakarta: Fakultas Teknologi Industri Universitas Ahmad Dahlan.

[5] Syafrudin, Chabib. 2013. Pembuatan Film Animasi Pendek "Dahsyatnya Sedekah" Berbasis Multimedia Menggunakan Teknik 2D Hybrid Animation Dengan Pemanfaatan Graphic. Skripsi. Yogyakarta: Fakultas Teknologi Industri Universitas Ahmad Dahlan.

[6] Hendriana, Y., \& Ariyana, R. Y. (2015, May). Multimedia adventure game folklore "Doyan Nada" for improving the cultural understanding of Sasak (Lombok) to children. In Intelligent Technology and Its Applications (ISITIA), 2015 International Seminar on (pp. 251-256). IEEE.

[7] Zahrotun, L., Hendriana, Y., \& Saputra, D. 2015. Learning Media Introduction of Yogyakarta Culture For Early Childhood 2-3 Years. International Journal of Computer Techniques (IJCT) V2 (5): Page (1-5).

[8] Chiong, R., \& Jankovic, L. (2008). Learning game strategy design through iterated Prisoner's Dilemma. International Journal of Computer Applications in Technology, 32(3), 216223.

[9] Uzoma, A. O., \& Nwachukwu, E. O. 2015. A Hybrid Prediction System for American NFL Results. International Journal of Computer Applications Technology and Research, 4(01), 42-47.

[10] Papastergiou, M. (2009). Digital game-based learning in high school computer science education: Impact on educational effectiveness and student motivation. Computers \& Education, 52(1), 1-12.

[11] Kiili, K. (2005). Digital game-based learning: Towards an experiential gaming model. The Internet and higher education, 8(1), 13-24

[12] Moreno-Ger, P., Burgos, D., Martínez-Ortiz, I., Sierra, J. L. \& Fernández-Manjón, B. (2008). Educational game design for online education. Computers in Human Behavior, 24(6), 2530-2540.

[13] Vaughan, William. 2012. Digital Modeling. s.1. : New Riders, 2012

[14] Suyanto. 2006. Merancang Film Kartun Kelas Dunia. Yogyakarta : Andi, 2006.

[15] Djalle, Zaharuddin G. 2007. The Making of 3D Animation Movie using 3DStudioMax. Bandung :Informatika, 2007. 